\title{
Improving quality of life after treatment for rectal cancer
}

Citation for published version (APA):

Beets, G. (2017). Improving quality of life after treatment for rectal cancer. Lancet, 390(10093), 432-434. https://doi.org/10.1016/S0140-6736(17)31545-3

Document status and date:

Published: 29/07/2017

DOI:

10.1016/S0140-6736(17)31545-3

Document Version:

Publisher's PDF, also known as Version of record

Document license:

Taverne

Please check the document version of this publication:

- A submitted manuscript is the version of the article upon submission and before peer-review. There can be important differences between the submitted version and the official published version of record.

People interested in the research are advised to contact the author for the final version of the publication, or visit the DOI to the publisher's website.

- The final author version and the galley proof are versions of the publication after peer review.

- The final published version features the final layout of the paper including the volume, issue and page numbers.

Link to publication

\footnotetext{
General rights rights.

- You may freely distribute the URL identifying the publication in the public portal. please follow below link for the End User Agreement:

www.umlib.nl/taverne-license

Take down policy

If you believe that this document breaches copyright please contact us at:

repository@maastrichtuniversity.nl

providing details and we will investigate your claim.
}

Copyright and moral rights for the publications made accessible in the public portal are retained by the authors and/or other copyright owners and it is a condition of accessing publications that users recognise and abide by the legal requirements associated with these

- Users may download and print one copy of any publication from the public portal for the purpose of private study or research.

- You may not further distribute the material or use it for any profit-making activity or commercial gain

If the publication is distributed under the terms of Article $25 \mathrm{fa}$ of the Dutch Copyright Act, indicated by the "Taverne" license above, 
of prognostic factors such as autoantibodies. When there are no factors associated with a poor prognosis, more conventional DMARDs are suggested. In patients with poor prognoses, the addition of a biologic or oral JAK kinase inhibitor is recommended, with current practice being to give biologics. One key limitation with the intensive use of conventional DMARDs, including triple therapy, is that trials and observational studies show these combinations are often discontinued over 6-12 months. ${ }^{3,12}$ To control active rheumatoid arthritis, some patients are bound to need injectable biologics or oral JAK inhibitors.

Costs were not assessed in the ORAL Strategy trial. Yet they will have crucial roles in JAK inhibitor use. Biologics for severe, active rheumatoid arthritis fall within, or above, the upper limits of acceptable cost-effectiveness. ${ }^{13}$ JAK inhibitors will only be used to any extent if their costeffectiveness is similar or better than biologics. When treatments have similar efficacy and risks, health-care funders expect the preferential use of the least expensive option. JAK inhibitors will only be used substantially if their cost is similar to biosimilars.

The ORAL Strategy trial highlights three benefits from the combination of tofacitinib and methotrexate in active rheumatoid arthritis. First, this combination's efficacy and toxicity are similar to injectable biologics such as adalimumab. Second, the onset of action of these drugs seems equally rapid. Third, most patients are able to remain on tofacitinib therapy for 12 months. These findings are extremely encouraging. They show the ongoing benefits of innovation in drug treatment. The trial also underlines the major flaw of all intensive treatment regimens in patients with active rheumatoid arthritis who did not respond to methotrexate. Only a few patients attain remission with any treatment strategy. Although effective rheumatoid arthritis treatments have expanded greatly in the past decade, its overall management still has substantial room for improvement.

\section{*David L Scott, Matt D Stevenson}

Department of Clinical Rheumatology, King's College London, Weston Education Centre, London SE5 9RJ, UK (DLS); and Department of Health Technology Assessment, Health Economics and Decision Science, School of Health and Related Research, University of Sheffield, Sheffield, UK (MDS) d.scott1@nhs.net

DLS has received funding from the National Institute for Health Research and Arthritis Research UK for studies of intensive treatment in rheumatoid arthritis. He has advised Eli Lilly and Company, Roche Products Ltd, Napp Pharmaceuticals, Baxalta, and Novartis. MDS has received grants from the National Institute for Health and Care Excellence (NICE) single technology appraisal and NICE multiple technology appraisal.

1 Fleischmann R, Mysler E, Hall S, et al, on behalf of the ORAL Strategy investigators. Efficacy and safety of tofacitinib monotherapy, tofacitinib with methotrexate, and adalimumab with methotrexate in patients with rheumatoid arthritis (ORAL Strategy): a phase 3b/4, double-blind, head-tohead, randomised controlled trial. Lancet 2017; published online June 16 http://dx.doi.org/10.1016/S0140-6736(17)31618-5.

2 O'Dell JR, Mikuls TR, Taylor TH, et al. Therapies for active rheumatoid arthritis after methotrexate failure. N EnglJ Med 2013; 369: 307-18.

3 Scott DL, Ibrahim F, Farewell V, et al. Tumour necrosis factor inhibitors versus combination intensive therapy with conventional disease modifying anti-rheumatic drugs in established rheumatoid arthritis: TACIT non-inferiority randomised controlled trial. BMJ 2015; 350: h1046.

4 Taylor PC, Keystone EC, van der Heijde D, et al. Baricitinib versus placebo or adalimumab in rheumatoid arthritis. N EnglJ Med 2017; 376: 652-62.

5 Kremer J, Li ZG, Hall S, et al. Tofacitinib in combination with nonbiologic disease-modifying antirheumatic drugs in patients with active rheumatoid arthritis: a randomized trial. Ann Intern Med 2013; 159: 253-61.

6 Singh JA, Hossain A, Tanjong Ghogomu E, et al. Biologics or tofacitinib for rheumatoid arthritis in incomplete responders to methotrexate or other traditional disease-modifying anti-rheumatic drugs: a systematic review and network meta-analysis. Cochrane Database Syst Rev 2016; 5: CD012183.

7 Nikiphorou E, Buch MH, Hyrich KL. Biologics registers in RA: methodological aspects, current role and future applications. Nat Rev Rheumatol 2017; published online June 1. DOI:10.1038/nrrheum.2017.81.

8 Tarp S, Furst DE, Boers M, et al. Risk of serious adverse effects of biological and targeted drugs in patients with rheumatoid arthritis: a systematic review meta-analysis. Rheumatology 2017; 56: 417-25.

9 Singh JA, Saag KG, Bridges SL Jr, et al. 2015 American College of Rheumatology guideline for the treatment of rheumatoid arthritis. Arthritis Care Res 2016; 68: 1-25.

10 Hazlewood GS, Barnabe C, Tomlinson G, et al. Methotrexate monotherapy and methotrexate combination therapy with traditional and biologic disease modifying antirheumatic drugs for rheumatoid arthritis: abridged Cochrane systematic review and network meta-analysis. BMJ 2016; 353: 11777 .

11 Smolen JS, Landewé R, Bijlsma J, et al. EULAR recommendations for the management of rheumatoid arthritis with synthetic and biological disease-modifying antirheumatic drugs: 2016 update. Ann Rheum Dis 2017; 76: 960-77.

12 Sauer BC, Teng CC, Tang D, et al. Persistence with conventional triple therapy versus a tumor necrosis factor inhibitor and methotrexate in US veterans with rheumatoid arthritis. Arthritis Care Res 2017; 69: 313-22.

13 Stevenson MD, Wailoo AJ, Tosh JC, et al. The cost-effectiveness of sequences of biological disease-modifying antirheumatic drug treatment in England fo patients with rheumatoid arthritis who can tolerate methotrexate. J Rheumatol 2017; published online Feb 17. DOI:10.3899/jrheum.160941.

\section{@ Improving quality of life after treatment for rectal cancer}

In rectal cancer, findings from large randomised trials have provided solid evidence that preoperative (chemo) radiotherapy decreases local recurrence rates by $50 \%$, compared with surgery alone. ${ }^{1}$ This decrease, however, comes at the cost of an increased incidence of anorectal and urogenital dysfunction, and, based on better imaging methods of today, many clinicians advocate a more selective policy of neodjuvant radiotherapy, with 
the goal of maintaining better quality of life. At the same time, there is a reverse strategy with the same goal of maintaining a better quality of life: start with radiotherapy and tailor subsequent surgery according to the response: total mesorectal excision after little or no response, local excision after a very good response, or even no surgery after a complete response. ${ }^{2}$ The rationale for these organ preservation strategies is that the major resections of the rectum are more responsible for any long-term functional problems and decreased quality of life than the radiotherapy. Two questions need to be addressed with such strategies: how much functional improvement occurs with these strategies compared with that from standard resection of the rectum; and how much, if any, is the associated oncological risk?

Randomised trials have been largely absent in the reports on organ preservation, and therefore the GRECCAR 2 study in The Lancet by Eric Rullier and colleagues ${ }^{3}$ is a very welcome endeavour to provide more high-level evidence. Patients with a T2T3 distal rectal carcinoma of a maximum of size $4 \mathrm{~cm}$ and a good clinical response to chemoradiation (residual tumour of a maximum of size $2 \mathrm{~cm}$ on MRI 6-8 weeks after chemoradiation) were randomly assigned to either local excision or standard total mesorectal excision surgery. At 2 years after surgery, one or more events from the composite primary outcome of death, recurrence, morbidity, and side-effects occurred in $41(56 \%)$ of 73 patients in the local excision group and $33(48 \%)$ of 69 in the total mesorectal excision group (odds ratio $1.33,95 \% \mathrm{Cl} 0.62-2 \cdot 86 ; \mathrm{p}=0.43$ ). Local excision was oncologically as safe as total mesorectal excision, but curiously, it was not better in terms of morbidity and long-term function.

These unexpected findings might relate to the details of the trial design. It seems as if during the design of GRECCCAR-2, there was a discussion about the choice of the main outcome measure: should it be an oncological endpoint, with a non-inferiority design requiring a large number of patients, or should it be a functional endpoint, with a superiority design requiring fewer patients. Eventually, both oncological and functional outcomes were incorporated in a composite endpoint, with an inherent risk of having insufficient power to assess the individual components. $15 \%$ of patients who were assigned to total mesorectal excision apparently refused to have it when the restaging revealed a very good response, and chose organ preservation instead.
This finding highlights the marked interest of patients in trying to avoid a stoma or a poor anorectal function. A second related observation from Rullier and colleagues' study is that around one of every four patients refused completion surgery when there were histological highrisk features after local excision. In other studies, 4.5 the number of patients who refused this type of surgery was even higher-around 50\%. Some patients have different perspectives on the balance of treatment risks and benefits than do health-care professionals.

Although GRECCAR-2 was a negative trial (ie, superiority of local excision over total mesorectal excision was not shown), it provides some direct and indirect valuable information. For example, if there is a marked patient preference for organ preservation in a randomised study, alternative trial designs should be considered that accommodate this, such as patient's preference, comprehensive cohort, randomised consent (Zelen) designs, cluster randomisation, or the cohort multiple randomised trial design. ${ }^{6} \mathrm{~A}$ longterm functional outcome as a main endpoint in organ preservation trials simplifies the analysis and requires fewer patients. Evidence so far suggests there are few or no real oncological disadvantages of organ preservation. From a pragmatic point of view, it is therefore better to study oncological outcomes through large registries rather than underpowered randomised trials.? Completion total mesorectal excision surgery after a local excision had a poor functional outcome, and was less often indicated than thought at the time of the trial design. Additionally, local excision can be omitted in patients with a clear clinical complete response, leading to further improvement of the functional results.

Maintaining a good quality of life is high on the priority list of patients, and should be high on physicians. It is our duty to find out how best to do so, and the information from Rullier and colleagues' study will be highly useful for designing future studies.

\section{Geerard Beets}

The Netherlands Cancer Institute, Amsterdam, 1066 CX, Netherlands; Maastricht University, Maastricht, Netherlands g.beets@nki.nl

I declare no competing interests.

1 Ma B, Gao P, Wang $\mathrm{H}$, et al. What has preoperative radio(chemo)therapy brought to localized rectal cancer patients in terms of perioperative and long-term outcomes over the past decades? A systematic review and meta-analysis based on 41,121 patients. Int J Cancer 2017; published May 30. DOI:10.1002/ijc.30805 
2 Beets GL, Figueiredo NF, Beets-Tan RG. Management of rectal cancer without radical resection. Annu Rev Med 2017; 68: 169-82.

3 Rullier E, Rouanet $P$, Tuech J-J, et al. Organ preservation for rectal cancer (GRECCAR 2): a prospective, randomised, open-label, multicentre, phase 3 trial. Lancet 2017; published online June 7. http://dx.doi.org/10.1016/ S0140-6736(17)31056-5.

4 Verseveld M, de Graaf EJ, Verhoef C, et al. Chemoradiation therapy for recta cancer in the distal rectum followed by organ-sparing transanal endoscopic microsurgery (CARTS study). BrJ Surg 2015; 102: 853-60.
5 Pucciarelli S, De Paoli A, Guerrieri M, et al. Local excision after preoperative chemoradiotherapy for rectal cancer: results of a multicenter phase II clinical trial. Dis Colon Rectum 2013; 56: 1349-56.

6 Relton C, Torgerson D, O'Cathain A, Nicholl J. Rethinking pragmatic randomised controlled trials: introducing the "cohort multiple randomised controlled trial" design. BMJ 2010; 340: c1066.

7 Beets GL, Figueiredo NL, Habr-Gama A, van de Velde CJ. A new paradigm for rectal cancer: organ preservation: introducing the International Watch \& Wait Database (IWWD). EurJ Surg Oncol 2015; 41: 1562-64.

\section{@ Post-partum depression-a glimpse of light in the darkness?}

Published Online

June 12, 2017 http://dx.doi.org/10.1016/ S0140-6736(17)31546-5

See Articles page 480
There can be little doubt about the importance of mood episodes in pregnancy and following childbirth. ${ }^{1}$ Mood episodes are common-post-partum depression is the most common medical complication of maternity, affecting around one in ten new mothers. ${ }^{2}$ They can also be severe-episodes of post-partum psychosis represent some of the most serious episodes of illness seen in psychiatry. ${ }^{3}$ Perinatal mood episodes cause substantial impairment to women and have a wide ranging impact on their babies, families, and society. The total long-term cost to society of perinatal depression, anxiety, and psychosis has been estimated to be $£ 8.1$ billion for each 1-year cohort of births in the UK. ${ }^{4}$

Despite the clear need, there are limited options for the management of these disorders. In addition to psychological approaches such as cognitive behavioural therapy, medications, particularly for more severe episodes of illness, are a mainstay of treatment. ${ }^{5}$ Because, at least in part, pregnant and breastfeeding women are excluded from clinical trials, decisions about

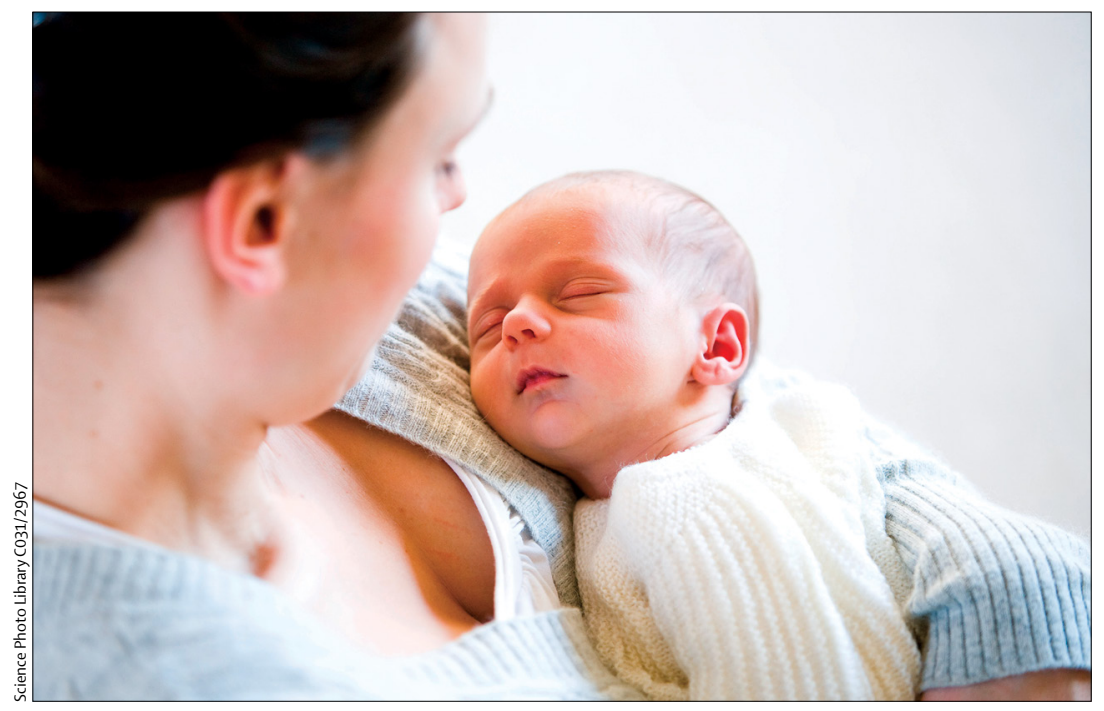

medication for perinatal mood episodes are difficult; they must be made by extrapolating the data available for their use at other times of women's lives. It is clear, therefore, that developing new, evidence-based treatments is essential.

In The Lancet, Stephen Kanes and colleagues ${ }^{6}$ report the results of a double-blind, randomised, placebo-controlled, phase 2 study of a new treatment for post-partum depression. The compound, brexanolone, is an intravenous formulation of allopregnanolone, a positive allosteric modulator of $\gamma$-aminobutyric acid (GABA) receptors. In this small study in 21 women with severe post-partum depression, infusion of brexanolone resulted in a rapid, sustained, statistically significant, and clinically meaningful response compared with placebo (at $60 \mathrm{~h}$, mean reduction in Hamilton Rating Scale for Depression [HAM-D] total score from baseline 21.0 points [SE 2.9] in the brexanolone group vs 8.8 points [SE 2.8] in the placebo group; difference $-12 \cdot 2,95 \% \mathrm{Cl}-3.67$ to $-20.77 ; p=0.0075$; effect size $1 \cdot 2)$. There were significant differences between groups from $24 \mathrm{~h}$; by $60 \mathrm{~h}$, seven (70\%) women in the brexanolone group had achieved remission compared with one (9\%) woman in the placebo group $(p=0.0364)$. These results, while based on a small sample, are very impressive; indeed, some readers might feel that they are too good to be true. For women with post-partum depression and the professionals who treat them, however, these findings are promising.

The investigators are to be applauded for targeting women with severe episodes of post-partum depression, and for showing that a clinical trial in women with this condition is feasible.

The current study, it must be noted, involved only ten women treated with brexanolone. The pressing 